Resumen por el autor, W. N. Hess, Cornell University, Ithaca.

Tráqueas en los brganos luminosos de algunos Lampíridos comunes.

Comparando los principales troncos traqueales y sus ramificaciones mas importantes en los segmentos abdominales de algunos de nuestros mas comunes lampíridos, el autor ha encontrado que la disposición de estas ramificaciones es semejante en cada segmento abdominal excepto en el noveno, y que no existen nuevas ramificaciones en adición a los principales troncos traqueales. La principal diferencia consiste en el excesivo tamaño de los tronoos principales y sus ramificaciones en los segmentos en que están colocados los organos luminosos. Aun cuando no nacen nuevas ramificaciones en los troncos principales, las que existen son mas gruesas y parecen dividirse mucho mas frecuentemente en ramillas mas y mas finas, que las que existen en otros segmentos abdominales, con el fín de aportar mayor cantidad de aire a los órganos luminosos.

En los machos de nuestros lampíridos mas luminosos algunos de los conectivos longitudinales de las tráqueas situadas en los segmentos que contienen los órganos productores de luz, en vez de unir entre si los troncos traqueales de estos segmentos, se han dividido y ramificado considerablemente, conduciendo directamente el aire a los órganos luminosos.

Translation by José F. Nonidez

Cornell Medical College, New York 
AUTHOR'S A BSTRACT OF THIS PAPER LBgDED

BY TUE BIBLIOGRAPBIC SERVICE, NOVEMBER 15

\title{
TRACHEATION OF THE LIGHT-ORGANS OF SOME COMMON LAMPYRIDAE ${ }^{1}$
}

\author{
WALTER N. HESS
}

TEN FIGURES

The light-organs of all the luminous fireflies that have been described occupy a part, or the entire ventral portion, of one or more abdominal segments. In a large per cent of luminous males the organs occupy the entire ventral portions of the sixth and seventh abdominal segments, while not infrequently the organs of the females are much smaller and restricted to a small area in the sixth segment. In our luminous larvae the organs are usually paired and lie in the ventro-lateral portion of the eighth abdominal segment.

The structure of the light-organs in all insects that have been studied, whether in the larva, pupa, or adult, appears to be very similar. They have always been found to consist of an inner, non-photogenic layer called the reflector and an outer luminous, or photogenic, layer (figs. 1 and 2).

The author is indebted to Dr. William A. Riley, under whose direction this study was made, for his helpful suggestions and criticisms.

Numerous workers have studied the structure of the mature light-organs, and in this connection many have figured the arrangement of the tracheal end-cells within the organ itself. Yet so far as any detailed study of the arrangement of the main tracheal trunks and branches that supply the light-organs is concerned, nothing seems to have been done except a brief work by Geipel ('15). He figured, in arsemidiagrammatic way, their arrangement in the male of Luciola africana. According to his

1 Contribution from the Entomological Laboratory of Cornell University. 


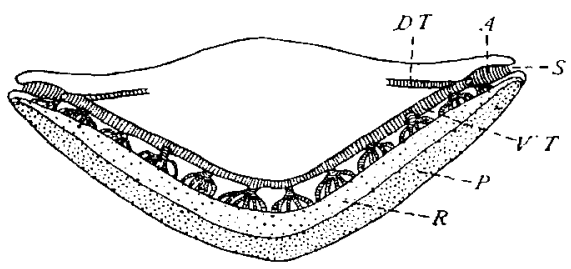

1
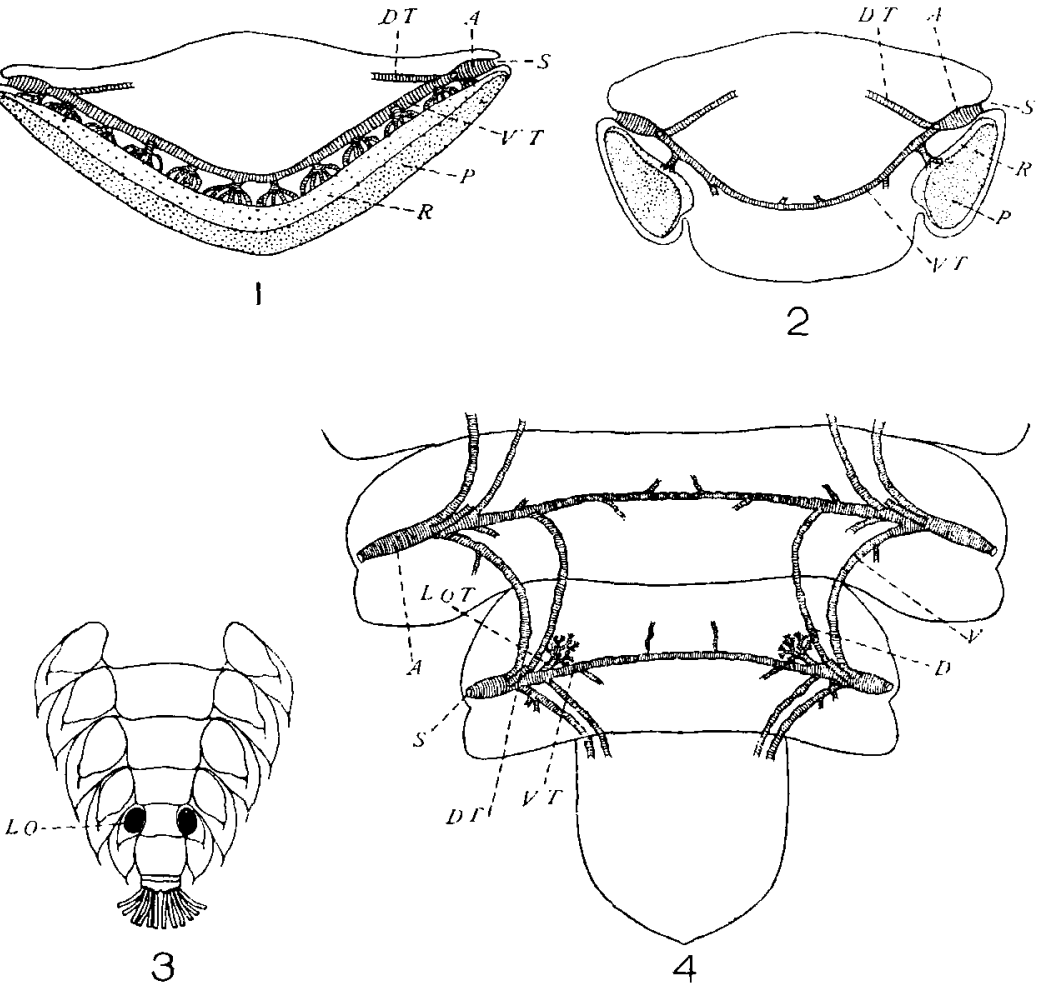

Fig. 1 Photinus scintillans, male, diagrammatic drawing to represent the two layers of the light-organ and the general arrangement of the larger trachea. A, ampulla; $D T$, dorsal tracheal trunk; $P$, photogenie layer; $R$, reflector layer; $S$, spiracle; $V T$, ventral tracheal trunk.

Fig. 2 Photurus pennsylvanica, larva, diagrammatic drawing to show the two layers of the light-organ, and the arrangement of the trachea. A, ampulla; $D T$, dorsal tracheal trunk; $P$, photogenic layer; $R$, reflector layer; $S$, spiracle; $V T$, ventral tracheal trunk.

Fig. 3 Photurus pennsylvanica, larva, ventral view of abdomen. The dark elliptical areas which are located on the eighth abdominal segment represent the larval light-organs, $L O$.

Fig. 4 Photurus pennsylvanica, larva, dorgal view of the principal trachea of the seventh and eighth abdominal segments. $A$, ampulla; $D$, dorsal longitudinal tracheal connective; $D T$, dorsal tracheal trunk; $L O T$, light-organ trachea; $S$, spiracle; $V$, ventral longitudinal tracheal connective. All tracheae shown with small branches supply the light-organ. 
description, the main tracheal branches arise irregularly from the ventral transverse tracheal connectives.

In order better to understand the general relation of the tracheal trunks and their branches which supply oxygen to the lightorgans of the adult and larva, a diagrammatic drawing was made of a cross-section through the seventh segment of a male of Photinus scintillans (fig. 1), and through the eighth abdominal segment of the larva of Photurus pennsylvanica (fig. 2). Both figures readily show the dorsal and ventral tracheal trunks which separate from the ampulla near the spiracle. In the case of the adult, the ventral trunk gives off numerous branches, which soon divide, sending their little tubes into the light-organ. These tubes pass through the reflector layer into the photogenic layer where they end in numerous tracheoles. The light-organs of the larva, however, are each supplied by one large tracheal branch, which leaves the ventral trunk near the ampulla. As it enters the light-organ it divides profusely, sending its branches throughout the region of the photogenic layer $(P)$.

In the larva of Photurus pennsylvanica (fig. $3, L O$ ) the lightorgans appear externally as two small oval areas on the ventrolateral sides of the eighth abdominal segment.

Since it was found that the arrangement of all the main tracheal branches in the different abdominal segments of the larva, except the ninth, are similar to those shown in the seventh and eighth segments (fig. 4), the trachea of only these two segments were figured. As can be readily seen by a comparison of the tracheation in these two abdominal segments, the branches arising from the transverse trunk in each segment are similar and they are bilaterally arranged. The trachea which supply oxygen to the light-organs in segment eight are simply enlarged branches which arise from the ventral transverse tracheal connective $(V T)$ and correspond to similar branches which arise from the ventral transverse tracheal connective in segment seven. The branch from the ventral tracheal trunk in segment eight which supplies the light-organ $(L O T)$ is shown with many of its branches.

The adult female of Photurus pennsylvanica, which is one of our largest native luminous fireflies, has the light-organs restricted 

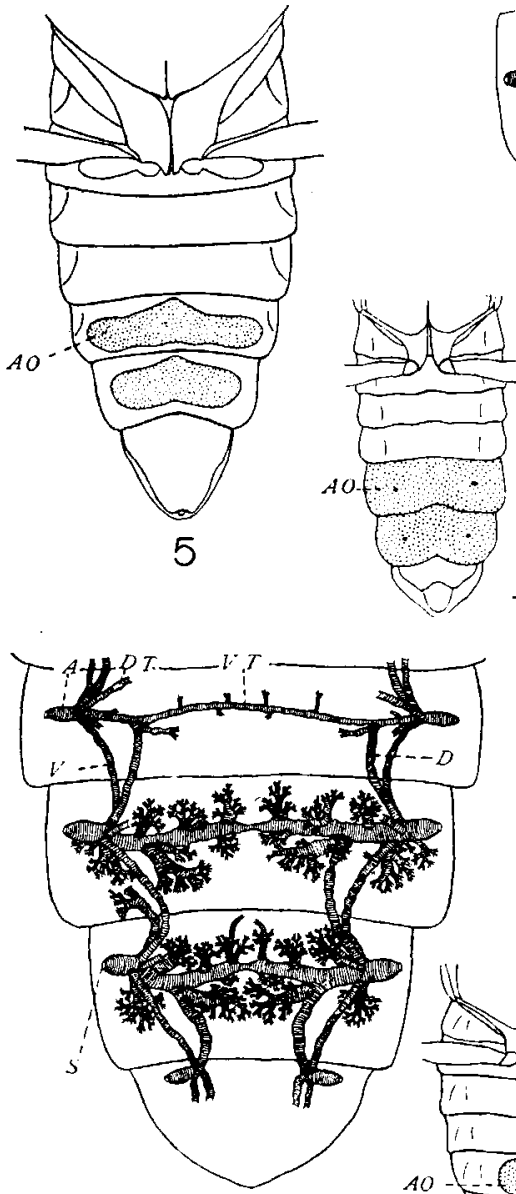

8
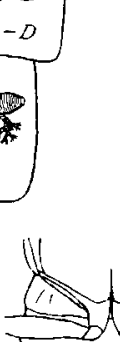

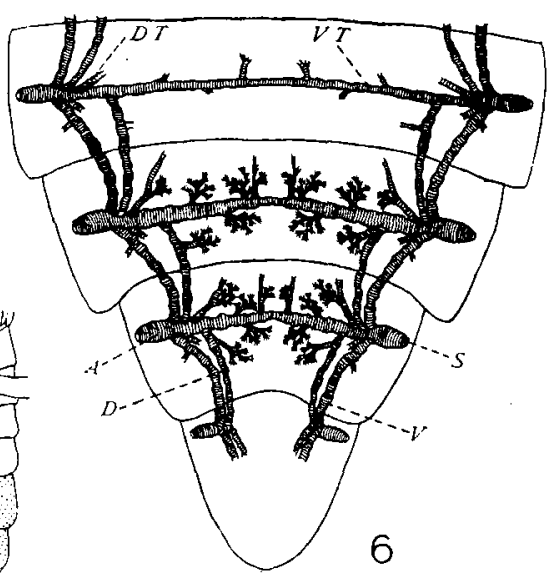

7

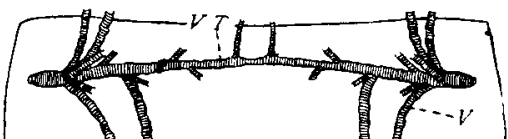

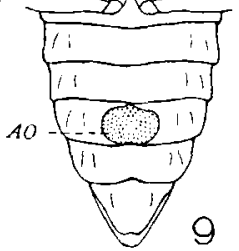
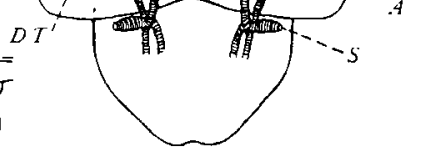

10

Fig. 5 Photorus yennsylvanica, female, ventral view of abdomen. The stippled areas on the sixth and seventh abdominal segments represent the adult light-organ $(A O)$.

Fig. 6 Photurus pennsylvanica, female, dorsal view of the principal trachea of the fifth, sixth, and seventh abdominal segments. For labels see figure 4.

Fig. 7 Photinus scintillans, male, ventral view of abdomen. The stippled areas on the sixth and seventh abdominal segments represent the adult lightorgan $(A O)$.

Fig. 8 Photinus scintillans, male, dorsal view of the principal trachea of the fifth, sixth, and seventh abdominal segments. For labels see figure 4.

Fig. 9 Photinus scintillans, female, ventral view of abdomen. The shaded area on the sixth abdominal segment represents the adult light-organ $(A O)$.

Fig. 10 Photinus scintillans, female, dorsal view of principal trachea of the fifth, sixth, and seventh abdominal segments. For labels see figure 4. 
to an area covering about two-thirds of the sternites of the sixth and seventh abdominal segments (fig. 5, $A O$ ). These organs are supplied with branches that arise from the ventral transverse tracheal connectives of the sixth and seventh abdominal segments, which are shown with their many branches (fig. 6). The arrangement of the tracheal branches in both segments is the same, and these branches correspond to similar trunks found in segment five, as well as to those in the other anterior abdominal segments. These trunks are much smaller than they are in the male, due to the fact that the organs are smaller, and hence they do not require as large an air supply.

The tracheation of the light-organs of the male Photurus pennsylvanica was not figured, as it was found to be similar to that of the male of Photinus scintillans, which will be discussed.

The adult male of Photinus scintillans, like most of our other luminous males, has its light-organs extensively developed so that they cover the entire sternites of the sixth and seventh abdominal segments (fig. 7, $A O$ ). The main tracheal trunks of this insect in the sixth and seventh abdominal segments were found to be of immense size (fig. 8), in order to supply the large amount of air that is needed by these light-organs. A brief description of these enlarged trunks will readily show the extreme of tracheal specialization for the supply of air to the light-organs of fireflies. The arrangement of the tracheal branches which arise from the ventral transverse tracheal connective of segment six is practically identical with the arrangement of the branches which arise from the corresponding trunk in segment five. The chief difference is that they are larger and the finer branches appear much more numerous. The arrangement of the branches in the sixth abdominal segment correspond very closely to those in the seventh abdominal segment. The longitudinal tracheal connectives between these two segments have a tendency to become modified into branches which supply the tissues of the light-organs, but no new branches were found to arise from the transverse tracheal connective of either segment. In the specimen that was figured the ventral longitudinal tracheal connective $(V)$ between segments six and seven, on the left side, is not 
continuous, but has divided near the middle, and has become much branched for the purpose of supplying air to the lightorgans. On the right side this connective, in the specimen which was drawn, was found to be very narrow, and at one point it showed evidence of a tendency to divide. The ventral transverse tracheal connectives in segments six and seven are very large from the spiracles to the center of the body. Here they become the same size as corresponding trachea in the other abdominal segments. In no case are accessory branches found to arise from the ventral transverse tracheal connectives, but the branches frequently divided and subdivided into numerous smaller branches, as soon as, or soon after, they arose from the main transverse trunks. A small amount of air for the light-organs evidently enters the spiracles of the fifth and eighth abdominal segments as certain of the longitudinal tracheal connectives leading from these segments to those of the light-organs are larger than in the other segments.

The female of Photinus scintillans, which has a very small light-organ in the sixth abdominal segment (fig. 9, $A O$ ) naturally has a reduced air supply. The main tracheal trunks of the sixth abdominal segment are somewhat enlarged (fig. 10), but they are small in comparison with the corresponding trunks in the male. As is also true of the other fireflies studied, no new tracheal branches are found to arise from the ventral transverse tracheal connectives, but these branches divide into numerous smaller branches in the region of the light-organs, for the purpose of supplying, with a large amount of air, the tissues of this structure.

By a comparison of the main tracheal trunks and their principal branches in the abdominal segments of some of our common Iuminous fireflies, it was found that the arrangement of these branches was similar in each abdominal segment except the ninth, and that no new branches were added. The chief difference was found in the excessive size of the main tracheal trunks and their branches in the segments where the light-organs were located. While no new branches arose from the main tracheal trunks, those present appeared to divide much more profusely into finer and 
finer branches than the corresponding trunks in the other abdominal segments, for the purpose of supplying a large amount of air to the light-organs. In the male fireflies of our most luminous species some of the longitudinal tracheal connectives in the segments containing the light-organs were not found connecting the tracheal trunks of these segments, but instead they were greatly branched supplying air directly to the light-organs. 